\title{
Occurrence of Campylobacter spp. in duck and associated environmental samples in Thrissur district ${ }^{\#}$
}

\author{
T. R. Athulya ${ }^{\star 1}$, C. Latha², B. Sunil ${ }^{3}$, J. Deepa ${ }^{4}$ and M. Shynu ${ }^{5}$ \\ Department of Veterinary Public Health, \\ College of Veterinary and Animal Sciences, Mannuthy, Thrissur- 680651 , \\ Kerala Veterinary and Animal Sciences University, Kerala, India.
}

Citation: Athulya, T. R., Latha, C., Sunil, B., Deepa, J. and Shynu, M. 2021. Occurrence of Campylobacter spp. in duck and associated environmental samples in Thrissur district. J. Vet. Anim. Sci. 52(4): 325-330

DOI: https://doi.org/10.51966/jvas.2021.52.4.325-330

Received: 05.02.2021

Accepted: 22.03.2021

Published: 15.12 .2021

\begin{abstract}
Campylobacteriosis caused by Campylobacter spp. is considered as the most common cause of bacterial diarrhoea in humans across the globe. The current research was undertaken to assess the occurrence of Campylobacter spp. in duck and the associated environmental samples. Among 220 samples analysed, 7.73 per cent samples revealed the presence of Campylobacter spp. Majority of the samples contained C. coli (4.55 per cent) and C. jejuni was detected in 3.18 per cent of the samples. The present study revealed a high occurrence of Campylobacter spp. in duck rearing facilities in Thrissur district, Kerala. As the demand for duck products is increasing every year, the risk of contamination by Campylobacter spp. has to be viewed seriously. The study revealed the importance of multifaceted one health approach including human medicine, veterinary medicine, epidemiology, environmental hygiene, public health institutes and epidemiological surveillance agencies to control food-borne diseases and up-gradation of biosecurity measures.
\end{abstract}

Keywords: Campylobacter spp. one health

Running Title: Occurrence of Campylobacter spp. in duck of Thrissur district

Campylobacter spp. is considered as an important cause for foodborne gastroenteritis in humans worldwide which is mostly associated with C. jejuni and C. coli (Wesley et al., 2000). Sporadic outbreaks often occur by consumption of raw or undercooked poultry products. In humans, the disease caused by Campylobacter spp. is normally mild and self-limiting, but severe systemic

"Part of MVSc thesis of first author submitted to Kerala Veterinary and Animal Sciences University, Pookode, Wayanad, Kerala

1. MVSc Scholar

2. Professor and Head

3. Professor

4. Assistant Professor

5. Associate Professor, Department of Veterinary Biochemistry

${ }^{*}$ Corresponding author: drathulyavet@gmail.com

Copyright: (C) 2021 Athulya et al. This is an open access article distributed under the terms of the Creative Commons Attribution 4.0 International License (http://creativecommons.org/licenses/by/4.0/), which permits unrestricted use, distribution, and reproduction in any medium, provided the original author and source are credited. 
infection can result in chronic sequelae such as Guillain-Barre syndrome (GBS), irritable bowel syndrome, Miller Fisher syndrome and reactive arthritis. The natural reservoirs of thermophilic campylobacters are free-living birds and commercial poultry. Despite duck being an important reservoir for Campylobacter spp. and a major part of modern Asian diet, information regarding the occurrence of the organism in duck is very limited. Therefore, the current investigation was designed with an objective to determine the occurrence of the Campylobacter spp. in duck rearing facilities.

\section{Materials and methods}

The current research was conducted to assess the occurrence of $C$. coli and $C$. jejuni in duck and environmental samples associated with duck rearing along with molecular confirmation of the positive isolates. The investigation was conducted for a period of 10 months from October 2019 to July 2020. A total of 220 samples from three different duck farms in and around Thrissur district were analysed during the study period. Samples consisted of duck cloacal swabs, soil and drinking water from duck farms. Details of samples are given in Table 1.

Isolation and identification of Campylobacter spp. from collected samples werecarried outbyselectiveenrichmentfollowed by selective plating as recommended by Stern et al. (2001) and OIE Terrestrial Manual (2017) with necessary modifications. Cloacal swab was streaked onto modified Charcoal Cefoperazone Deoxycholate Agar plates supplemented with Polymyxin B (P-mCCDA). The plates were then incubated at $42^{\circ} \mathrm{C}$ for $48 \mathrm{~h}$ under microaerophilic conditions. Soil and drinking water samples were subjected to enrichment in mCCD (modified Charcoal Cefoperazone Deoxycholate) broth supplemented with CCDA selective supplement (FD 135). Incubation was done under microaerophilic conditions at $42^{\circ} \mathrm{C}$ for $48 \mathrm{~h}$ followed by selective plating onto mCCDA supplemented with CAT selective supplement (FD 145), Campylobacter supplement V (FD 067) and Polymyxin B selective supplement (FD 003). It was then incubated under microaerophilic conditions at $42^{\circ} \mathrm{C}$ for $48 \mathrm{~h}$. Greyish, flat, spreading type, shiny, mucoid and moistened colonies with tendency to spread and with or without metallic sheen were considered as Campylobacter spp. (Fig. 1).

The confirmation of Campylobacter spp. was carried out as per the procedure described by El-Adawy et al. (2012) with slight modifications by subjecting all the positive Campylobacter isolates to multiplexpolymerase chain reaction. The positive isolates were further analysed for the presence of $16 S$ rRNA gene specific for Campylobacter genus and virulence gene cadF. C. coli and C. jejuni were identified by the detection of ceuE gene specific for $C$. coli and mapA gene specific for $C$. jejuni. The target genes that were detected by MPCR and the primer sequences used in the study are shown in Table 2. A master mix was prepared for each Campylobacter spp. before setting up of the PCR reaction by combining the reagents as depicted in Table 3. Cycling conditions for mPCR are depicted in Table 4. The PCR products were stained with SYBR safe dye and detected by submarine gel electrophoresis.

\section{Results and discussion}

\section{Cloacal swabs of duck}

Per cent occurrence of Campylobacter spp. is given in Table 5 . The presence of Campylobacter spp. in DF2 (22.5 per cent) was significantly higher $(p<0.05)$ compared to DF3

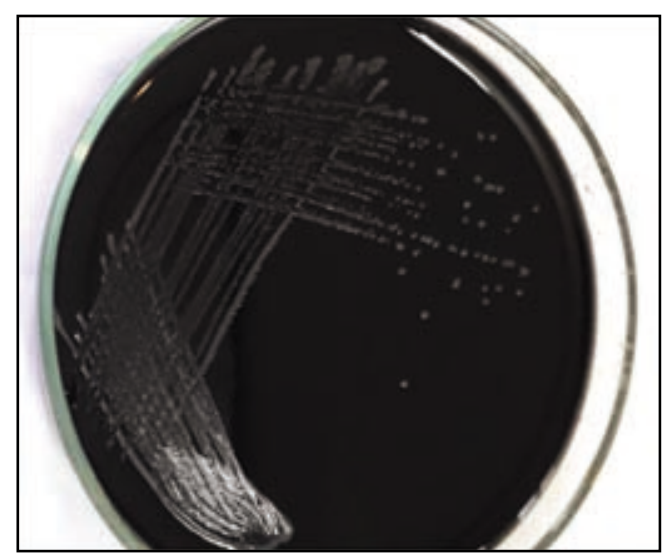

Fig. 1. Greyish, round, spreading type, shiny, moistened colonies of Campylobacter spp. on mCCD agar 
Table 1. Details of sample collection

\begin{tabular}{|c|c|c|c|c|}
\hline SI. No. & Duck farm & Cloacal swabs & Soil & Water \\
\hline 1 & DF1 & 40 & 15 & 15 \\
\hline 2 & DF2 & 40 & 15 & 15 \\
\hline 3 & DF3 & 40 & 20 & 20 \\
\hline \multicolumn{2}{|c|}{ Total } & $\mathbf{1 2 0}$ & $\mathbf{5 0}$ & $\mathbf{5 0}$ \\
\hline
\end{tabular}

Table 2. Primers used for the identification of Campylobacter spp.

\begin{tabular}{|c|c|c|c|}
\hline Primer & Primer sequence & Size (bp) & Reference \\
\hline 16SrRNA F & 5'-GGATGACACTTTTCGGAGC-3' & \multirow{2}{*}{816} & \multirow{2}{*}{$\begin{array}{l}\text { Linton et al. } \\
\quad(1996)\end{array}$} \\
\hline 16S rRNA R & 5'-CATTGTAGCACGTGTGTC-3' & & \\
\hline cadF F & 5'TTGAAGGTAATTTAGATATG-3' & \multirow{2}{*}{400} & \multirow{2}{*}{$\begin{array}{l}\text { Rozynek et al. } \\
\qquad(2005)\end{array}$} \\
\hline cadF R & 5'-CTAATACCTAAAGTTGAAAC-3' & & \\
\hline mapA F & 5'-CTATTTTATTTTTGAGTGCTTGTG-3' & \multirow{2}{*}{589} & \multirow{2}{*}{$\begin{array}{c}\text { Denis et al. } \\
(1999)\end{array}$} \\
\hline mapA R & 5'-GCTTTATTTGCCATTTGTTTTATTA-3' & & \\
\hline ceuE F & 5'-AATTGAAAATTGCTCCAACTATG-3' & \multirow{2}{*}{462} & \multirow{2}{*}{$\begin{array}{l}\text { Denis et al. } \\
(1999)\end{array}$} \\
\hline ceuE R & 5'-TGATTTTATTATTTGTAGCAGCG-3' & & \\
\hline
\end{tabular}

Table 3. Components of multiplex PCR mixture

\begin{tabular}{|c|l|c|c|}
\hline $\begin{array}{c}\text { SI. } \\
\text { No. }\end{array}$ & \multicolumn{1}{|c|}{ Name of the reagent } & $\begin{array}{c}\text { Stock } \\
\text { Concentration }\end{array}$ & $\begin{array}{c}\text { Quantity } \\
(\boldsymbol{\mu} \mathrm{L})\end{array}$ \\
\hline 1 & Template DNA & $50 \mathrm{ng} / \mu \mathrm{L}$ & 5.00 \\
\hline 2 & $10 \mathrm{X}$ PCR buffer & $200 \mathrm{mM}$ & 3.00 \\
\hline 3 & $\mathrm{MgCl}_{2}$ & $25 \mathrm{mM}$ & 2.00 \\
\hline 4 & Taq DNA polymerase & $5 \mathrm{Units} / \mu \mathrm{L}$ & 0.75 \\
\hline 5 & dNTP Mix & $2 \mathrm{mM}$ each & 2.50 \\
\hline 6 & Forward primer of $16 S \mathrm{RNA}$ gene & $10 \mathrm{pmoles} / \mu \mathrm{L}$ & 1.00 \\
\hline 7 & Reverse primer of $16 S \mathrm{RNA}$ gene & $10 \mathrm{pmoles} / \mu \mathrm{L}$ & 1.00 \\
\hline 8 & Forward primer of cadF gene & $20 \mathrm{pmoles} / \mu \mathrm{L}$ & 1.00 \\
\hline 9 & Reverse primer of $c a d F$ gene & $20 \mathrm{pmoles} / \mu \mathrm{L}$ & 1.00 \\
\hline 10 & Forward primer of $m a p A$ gene & $10 \mathrm{pmoles} / \mu \mathrm{L}$ & 1.00 \\
\hline 11 & Reverse primer of mapA gene & $10 \mathrm{pmoles} / \mu \mathrm{L}$ & 1.00 \\
\hline 12 & Forward primer of ceuE gene & $10 \mathrm{pmoles} / \mu \mathrm{L}$ & 1.00 \\
\hline 13 & Reverse primer of ceuE gene & $10 \mathrm{pmoles} / \mu \mathrm{L}$ & 1.00 \\
\hline 14 & Nuclease free water & & 8.75 \\
\hline & $\quad$ Total & $\mathbf{3 0 . 0 0}$ \\
\hline
\end{tabular}

(2.5 per cent). In the present study, 10 per cent of the total 120 cloacal swabs from ducks were positive for the organism which was in perfect tune with the results of Nor Faiza et al. (2013), where the authors reported an occurrence of the organism in 12 per cent cloacal swab samples of duck collected from Malaysia. However, Wei et al. (2014) in South Korea isolated Campylobacter spp. from 96.6 per cent of duck cloacal swabs. The farm with highest occurrence in the current study had muddy and wet floor compared to the other two farms with rather clean and dry environment.

\section{Soil samples}

In the present study, two (13.33 per cent) soil samples each from DF1 and DF2 carried the organism while none of the samples from DF3 harbored the same. There was no significant difference among the three duck farms regarding the occurrence of Campylobacter spp. in soil. The lower occurrence in the current research can be correlated with zero prevalence of the organism in soil samples reported by Adzitey et al. (2012) which could possibly be due to the poor 
Table 4. Cycling conditions used for PCR of $16 S$ rRNA, cadF, mapA and ceuE genes

\begin{tabular}{|c|l|c|c|c|}
\hline SI. No. & \multicolumn{1}{|c|}{ Steps } & Temperature & Time (min) & No. of Cycles \\
\hline 1 & Initial denaturation & $95.0^{\circ} \mathrm{C}$ & 10 & 1 \\
\hline 2 & Denaturation & $94.0^{\circ} \mathrm{C}$ & 1 & \multirow{2}{*}{30} \\
\hline 3 & Annealing & $51.8^{\circ} \mathrm{C}$ & 1 & \\
\hline 4 & Extension & $72.0^{\circ} \mathrm{C}$ & 1 & 1 \\
\hline 5 & Final extension & $72.0^{\circ} \mathrm{C}$ & 10 & \\
\hline 6 & Hold & $4.0^{\circ} \mathrm{C}$ & 10 & \multirow{2}{*}{} \\
\hline
\end{tabular}

Table 5. Occurrence of Campylobacter spp. in duck rearing facilities

\begin{tabular}{|c|c|c|c|c|c|c|c|c|c|}
\hline \multirow{3}{*}{ SI. No. } & \multirow{3}{*}{ Duck farm } & \multicolumn{8}{|c|}{ Positive samples } \\
\hline & & \multicolumn{2}{|c|}{ Cloacal swab } & \multicolumn{2}{|c|}{ Soil } & \multicolumn{2}{|c|}{ Water } & \multicolumn{2}{|c|}{ Total } \\
\hline & & No. & Per cent & No. & Per cent & No. & Per cent & No. & Per cent \\
\hline 1 & DF1 & 2 & $5.00^{a, b}$ & 2 & $13.33^{a}$ & 1 & $6.67^{a}$ & 5 & $7.14^{a, b}$ \\
\hline 2 & DF2 & 9 & $22.50^{b}$ & 2 & $13.33^{a}$ & 0 & $0.00^{a}$ & 11 & $15.71^{b}$ \\
\hline 3 & DF3 & 1 & $2.50^{a}$ & 0 & $0.00^{a}$ & 0 & $0.00^{a}$ & 1 & $1.25^{\mathrm{a}}$ \\
\hline & Total & 12 & 10.00 & 4 & 8.00 & 1 & 2.00 & 17 & 7.73 \\
\hline
\end{tabular}

Figures bearing same superscripts do not differ significantly $(p<0.05)$

Table 6. Distribution of genes in Campylobacter spp. isolates of duck rearing facilities

\begin{tabular}{|c|c|c|c|c|c|c|}
\hline \multirow{2}{*}{$\begin{array}{c}\text { SI. } \\
\text { No. }\end{array}$} & \multirow{2}{*}{ Farm } & \multirow{2}{*}{$\begin{array}{c}\text { No of isolates } \\
\text { tested }\end{array}$} & \multicolumn{4}{|c|}{ Distribution of genes in the positive isolates (No.) } \\
\cline { 4 - 7 } & & 5 & $\mathbf{1 6 S}$ rRNA & ceuE & mapA & cadF \\
\hline 1 & DF1 & 11 & 11 & 2 & 3 & 3 \\
\hline 2 & DF2 & 1 & 1 & 0 & 3 & 3 \\
\hline 3 & DF3 & $\mathbf{1 7}$ & $\mathbf{1 7}$ & $\mathbf{1 0}$ & $\mathbf{7}$ & $\mathbf{7}$ \\
\hline
\end{tabular}

survivability of the organism in soil. The results of the present study are contrary to that of Jensen et al. (2006) in Denmark, where the authors attributed the paddock contamination with Campylobacter spp. to the higher prevalence (35 per cent) in environmental samples. The occurrence recorded in the current study could be due to spill-over infections to soil from poultry reservoirs.

\section{Water}

Only one drinking water sample (collected from DF1) from duck rearing facilities was positive for the organism. There was no significant differenceamongthethreeduckfarms regarding the occurrence of Campylobacter spp. in water. The results can be correlated with that of Adzitey et al. (2012), where none of the drinking water samples collected from duck farm harbored the organism. On the other hand, Van-Dyke et al. (2010) and Aung et al. (2015) recorded higher prevalence of Campylobacter spp. in water samples collected from Canada and Malaysia, respectively. The low recovery rate of the organism in the present research might be either due to the absence of the organism in water or the poor survivability of the organism in feed, soil, water and other surfaces exposed to sunlight, high oxygen tension and dry environment.

\section{Overall occurrence in duck rearing facilities}

Comparing the three duck farms under study, the occurrence of Campylobacter spp. in DF2 (15.71 per cent) was significantly higher $(p<0.05)$ than DF3 (1.25 per cent). In farm DF1, 7.14 per cent samples were positive for the organism. The overall occurrence of Campylobacter spp. in duck rearing facilities was 7.73 per cent (Table 5). Kafshdouzan et al. (2019) reported an occurrence of the organism in 17.33 per cent of duck samples collected from Iran. An incidence of 73 per cent of $C$. jejuni was reported by Pacha et al. (1988) from migratory ducks in Pacific North American flyway. The low 
recovery of the organism from majority of the samples in the current study could be possibly due to its poor survivability in the environment.

\section{Molecular confirmation of the isolates from duck rearing facilities by $\mathrm{MPCR}$}

All the 17 isolates obtained from duck rearing facilities were subjected to $\mathrm{MPCR}$ for the simultaneous detection of Campylobacter genus specific 16S rRNA gene, a conserved virulence cadF gene, $C$. coli specific ceuE gene and $C$. jejuni specific mapA gene. The result of $\mathrm{mPCR}$ is depicted in Table 6.

Among the total 220 samples collected from duck rearing facilities, majority of the samples harbored C. coli (4.55 per cent) followed by $C$. jejuni (3.18 per cent). Nor-Faiza et al. (2013) also reported a higher occurrence of $C$. coli (88 per cent of total isolates) in duck samples collected from Malaysia compared to C. jejuni. On the other hand, according to Wei et al. (2014) and Jamali et al. (2015), C. jejuni was the predominant isolate from duck samples, accounting for more than 80 per cent of the positive isolates. The relative proportion of Campylobacter colonisation in gastrointestinal tract varies with different geographical area and type of host. This could be the reason for differences observed by several authors regarding occurrence of the two Campylobacter species.

\section{Conclusion}

All the three duck farms followed semiintensive system of duck rearing, thus enhancing the chances of horizontal transmission of organismfromtheenvironment.Physicalbarriers that are capable of restricting the access to duck houses and external environment around the farms should be implemented to prevent the introduction of Campylobacter spp. via farmers, animals and visitors. Along with that, stringent biosecurity measures are required to prevent the contamination and propagation of organism among different flocks.

\section{Acknowledgment}

ICAR- Outreach Programme on Zoonotic Diseases for funding the research

\section{Conflict of interest}

The authors declare that they have no conflict of interest.

\section{References}

Adzitey, F., Rusul, G., Huda, N., Cogan, T. and Corry, J. 2012. Prevalence, antibiotic resistance and RAPD typing of Campylobacter species isolated from ducks, their rearing and processing environments in Penang, Malaysia. Int. J. Food Microbiol. 154: 197-205.

Aung, W.W., Saleha, A.A., Zunita, Z., Murugaiyah, M., Aliyu, A.B., Goni, D.M. and Mohamed, A.M. 2015. Occurrence of Campylobacter in dairy and beef cattle and their farm environment in Malaysia. Pakist. Vet. J. 35: 470-473.

Denis, M., Soumet, C., Rivoal, K., Ermel, G., Blivet, D., Salvat, G. and Colin, P. 1999. Development of m-PCR assay for simultaneous identification of Campylobacter jejuni and C. coli. Lett. Appl. Microbiol. 29: 406-410.

El-Adawy, H., Hotzel, H., Tomaso, H., Neubauer, H. and Hafez, H.M. 2012. Elucidation of colonization time and prevalence of thermophilic Campylobacter species during turkey rearing using multiplex polymerase chain reaction. Poult. Sci. 91: 454-459.

Jamali, H., Ghaderpour, A., Radmehr, B., Wei, K.S.C., Chai, L.C. and Ismail, S. 2015. Prevalence and antimicrobial resistance of Campylobacter species isolates in ducks and geese. Food Control. 50: 3 28-330.

Jensen, A.N., Dalsgaard, A.D.L., Baggesen. and Nielsen, E.M. 2006. The occurrence and characterization of Campylobacter jejuni and C. coli in organic pigs and their outdoor environment. J. Vet. Microbiol. 116: 96-105.

Kafshdouzan, K., Ashrafi-Tamai, I. and Pouyan, S. 2019. Detection of faecal 
contamination with Campylobacter jejuni and Campylobacter coli in urban ducks in the North of Iran. J. Vet. Res. 74: 284-289.

Linton, D., Owen, R.J. and Stanley, J. 1996. Rapid identification by PCR of the genus CampylobacterandoffiveCampylobacter species enteropathogenic for man and animals. Res. Microbiol. 147: 707-718.

Nor Faiza, S., Saleha, A.A., Jalila, A. and Fauziah, N. 2013. Research note occurrence of Campylobacter and Salmonella in ducks and duck eggs in Selangor, Malaysia. Trop. Biomed. 30: 155-158.

OIE. 2017. Terrestrial Manual. (Chapter 2.9.3.). Campylobacter coli and C. jejuni. World Organization for Animal Health, 9p.

Pacha, R.E., Clark, G.W., Williams, E.A. and Carter, A.M. 1988. Migratory birds of central Washington as reservoirs of Campylobacter jejuni. Can. J. Microbiol. 34: 80-82.

Rozynek, E., Dzierzanowska-Fangrat, K., Jozwiak, P., Popowski, J., Korsak, D. and Dzierzanowska, D. 2005. Prevalence of potential virulence markers in Polish CampylobacterjejuniandCampylobacter coli isolates obtained from hospitalized children and from chicken carcasses. $J$. Med. Microbiol. 54: 615-619.
Sahin, O., Morishita, T. and Zhang, Q. 2002. Campylobacter colonization in poultry:sources of infection and modes of transmission. Anim. Hlth. Res. Rev. 3: 95-105.

Stern, N.J., Line, J.E. and Chen, H.C. 2001. Campylobacter. In: Downes, F.P. and Ito, K. (eds.), Compendium of Methods for the Microbiological Examination of Foods. (4th Ed.). American Public Health Association, Washington, D. C. pp. 301310.

Van-Dyke, M.I., Morton, V.K., McLellan, N.L. and Huck, P.M. 2010. The occurrence of Campylobacter in river water and waterfowl within a watershed in southern Ontario, Canada. J. Appl. Microbiol. 109: 1053-1066.

Wei, B., Cha, S.Y., Kang, M., Roh, J.H., Seo, H.S., Yoon, R.H. and Jang, H.K. 2014. Antimicrobial susceptibility profiles and molecular typing of Campylobacterjejuni and Campylobacter coli isolates from ducks in South Korea. Appl. Environ. Microbiol. 80: 7604-7610.

Wesley, I.V., Wells, S.J., Harmon, K.M., Green, A., Schroeder-Tucker, L., Glover, M. and Siddique, I. 2000. Fecal shedding of Campylobacter and Arcobacter spp. in dairy cattle. Appl. Environ. Microbiol. 66: 1994-2000. 